\title{
Faktor-Faktor Yang Mempengaruhi Sensitivitas Etis
}

\author{
Yoseva Anjelina \\ Universitas Katolik Soegijapranata Semarang \\ yosevaanjelina@gmail.com
}

\begin{abstract}
This study examines determinants of ethical sensitivity. Specifically, this study investigates whether ethical reasoning and personal character (the level of idealism, the level of relativism, locus of control, age, cumulative achievement index and sex, ) have an effect on ethical sensitivity.The samples are accounting students of Catholic University Soegijapranata Semarang and uses multiple regression to test the hypotheses. The results of this study indicate that (1) ethical reasoning has an effect on the ethical sensitivity (2) the level of idealism has a positive effect on ethical sensitivity (3) the level of relativism negatively affect the ethical sensitivity (4) locus of control, age, achievement index and gender have no effect on ethical sesitiviys.
\end{abstract}

Keywords: EthicalsSensitivity, ethical reasoning, ethical orientation, locus of control, demographic factors

\begin{abstract}
Abstrak
Penelitian ini menguji determinan sensitivitas etis. Secara spesifik, penelitian ini menguji apakah ethical reasoning dan karakter personal (tingkat idealisme, tingkat relativisme, locus of control, usia, indeks prestasi kumulatif dan jenis kelamin,) berpengaruh terhadap sensitivitas etis. Sampel diambil dari mahasiswa akuntansi Universitas Katolik Soegijapranata Semarang dengan teknik purposive sampling. Penelitian ini menggunakan analisis regresi untuk pengujian hipotesis. Hasil dari penelitian ini menunjukkan bahwa (1) ethical reasoning berpengaruh terhadap sensitivitas etis (2) tingkat idealisme berpengaruh positif terhadap sensitivitas etis (3) tingkat relativisme berpengaruh negatif terhadap sensitivitas etis (4) locus of control, usia, indeks prestasi dan jenis kelamin tidak berpengaruh terhadap sesitivitas etis.
\end{abstract}

Kata Kunci : Sensitivititas etis, ethical reasoning, orientasi etika, locus of control, faktor demografik.

\section{PENDAHULUAN}

Perilaku etis merupakan perilaku yang sesuai dengan norma, nilai, dan hukum yang berlaku. Norma tersebut berfungsi sebagai pegangan seseorang dalam bertingkah laku (Bertens, 1994). Perilaku etis sangat bermanfaat untuk kepentingan pribadi dan untuk berinteraksi di lingkungan sosial. Profesi akuntan berkaitan erat dengan masalah etis. 
Perilaku etis akuntan bisa mempengaruhi kredibilitasnya. Akuntan berperan sebagai penyedia informasi bagi pelaku bisnis dalam pembuatan keputusan. Keputusan yang diambil tentunya berdampak bagi orang lain. Oleh karena itu, pertimbangan etis merupakan hal yang sangat penting dalam dunia pekerjaan.

Kode Etik Akuntan Indonesia yaitu sebuah etika profesi yang berisi norma perilaku yang mengatur hubungan antara akuntan publik dengan klien, rekan sejawat, dan masyarakat. Kode etik tersebut memuat prinsip-prinsip etika sebagai akuntan publik, yaitu tanggung jawab profesi, kepentingan publik, integritas, objektivitas, kompetensi dan kehati-hatian profesional, kerahasiaan, perilaku profesional, dan standar teknis (Agoes dan I Cenik, 2009). Prinsip-prinsip tersebut menjadi pedoman akuntan dalam menjalankan profesinya.

Namun pada kenyataannya, profesi akuntan rentan terhadap kecurangan dan pelanggaran. Seperti yang terjadi pada perusahaan di Amerika Serikat yaitu Enron dan Worldcom yang memanipulasi laporan keuangan. Kasus serupa juga terjadi di Indonesia yaitu terkuaknya kecurangan pelaporan keuangan PT. Kereta Api Indonesia (Perseroan). Selain itu ada beberapa kasus lain misalnya kasus KPMG-Siddharta Siddharta dan Harsono yang diduga menyuap pajak (2001), kasus PT Muzatek Jaya (2004), kasus Mulyana W. Kusuma - Anggota KPU (2004), dan kasus kredit macet BRI cabang Jambi (2010).

Interaksi seorang akuntan dengan berbagai pihak pemangku kepentingan baik individual, entitas, maupun organisasi menjadi salah satu faktor potensial penyebab munculnya konflik dalam lingkup pekerjaan. Hal ini akan mengakibatkan hilangnya kepercayaan publik terhadap profesi akuntan. Pengetahuan, pemahaman, serta kemauan akuntan menerapkan nilai-nilai moral dan etika sangat penting untuk meminimalkan terjadinya konflik (Ludigdo, 1999b dalam Marwanto, 2007). Oleh karena itu, pendidikan akuntansi berkaitan dengan etika, turut berpengaruh terhadap pembentukkan perilaku etis auditor.

Penelitian mengenai masalah etis dalam akuntansi berfokus pada tiga bidang utama, yaitu pengembangan etika, penilaian etika dan pendidikan etika. Pengembangan etika berfokus pada pembelajaran ethical reasoning berdasarkan praktik akuntan dan auditor ( Shaub, 1989, 1994; Cohen, Laurie dan David, 2001; Elias, 2002 dan Buchan, 2005). Penilaian etika bertujuan untuk menguji hubungan antara ethical reasoning dan perilaku moral akuntan dalam konteks akuntansi audit (Allen dan Chee, 2001; Chiu, 2003; Gul, Andy dan Marian, 2003; Chan dan Leung, 2006). Pendidikan etika mengkaji efektifitas pendidikan dalam meningkatkan sikap etis dan keterampilan ethical reasoning mahasiswa akuntansi dan praktisi (Molyneaux, 2004 dan Mele, 2005).

Rest (1983) yang dikutip dalam Chan dan Leung (2006) mengemukakan bahwa perilaku moral yang membentuk kepribadian seseorang terdiri dari empat proses dasar psikologi yaitu sensitivitas moral (moral sensitivity), penilaian moral (moral judgment), motivasi moral (moral motivation) dan karakter moral (moral character). Moral sensitivity menjelaskan kepekaan atau kepedulian seseorang pada efek perilakunya terhadap orang lain. Moral judgment merupakan penilaian atau pertimbangan tindakan mana yang benar atau salah secara moral. Moral motivation memprioritaskan nilai moral yang relatif berhubungan dengan nilai lainnya. Moral character yaitu kebenaran, ketahanan, tindakan moral atau perilaku. 
Dengan mengacu pada pendapat Rest (1983) tersebut, beberapa ahli melakukan penelitian mengenai etika. Namun sebagian besar penelitian-penelitian tersebut meneliti mengenai komponen moral judgment. Diantaranya adalah Ryan J.J (2001), Allen dan Chee (2001), Uddin dan Gillett (2002), Gul, Andy dan Marian (2003) dan Chiu (2003). Hal tersebut menjadi pertimbangan mengapa Chan dan Leung (2006) lebih memfokuskan pada komponen pertama yaitu sensitivitas etis. Beberapa peneliti seperti Chan dan Leung (2006), Marwanto (2007), Wiyantoro dkk. (2011), dan Sinaga (2015), meneliti pengaruh ethical reasoning dan karakteristik personal (orientasi etika, locus of control, jenis kelamin, usia dan prestasi akademik) mahasiswa akuntansi terhadap sensitivitas etis.

Sensitivitas etis merupakan kepekaan individu terhadap permasalahan etika. Ketika dihadapkan dalam suatu permasalahan, seorang akuntan harus memiliki kemampuan tersebut sebelum mengambil keputusan. Oleh karena itu, sensitivitas etis berperan penting bagi akuntan. Ada beberapa faktor yang mempengaruhi sensitivitas etis, diantaranya adalah ethical reasoning dan karakteristik personal. Ethical reasoning merupakan pertimbangan atau pemikiran untuk memberikan beberapa alasan apakah suatu kejadian tergolong dalam cakupan etis atau bukan. Seorang akuntan harus mampu menafsirkan apakah suatu tindakan tersebut etis atau tidak.

Ada dua karakteristik orientasi etika yaitu idealisme dan relativisme. Idealisme merupakan fase dimana seorang individu percaya bahwa konsekuensi yang dimiliki dan diinginkan tidak melanggar nilai-nilai moral. Seorang yang idealis akan menghindari tindakan yang merugikan orang lain. Relativisme merupakan fase dimana seorang memiliki kepercayaan untuk dapat menolak moral dalam perilakunya. Locus of control merupakan suatu ciri kepribadian seseorang yang memberikan pengaruh internal dan eksternal dalam pembuatan keputusan.

Faktor lain yang mempengaruhi sensitivitas etis adalah demografi. Faktor demografi yang digunakan dalam penelitian ini antara lain usia, prestasi akademik, dan jenis kelamin. Seseorang yang berusia lebih tua akan memiliki cara pandang dan kemampuan dalam menafsirkan suatu masalah yang berbeda dibandingkan dengan seseorang yang berusia lebih muda. Prestasi akademik seseorang berhubungan dengan senstivitas etis. Semakin tinggi prestasi yang dimiliki seseorang akan menunjukkan pola pikir dalam membedakan suatu permasalahan. Jenis kelamin juga memiliki hubungan dengan sensitivitas etis. Pria dan wanita memiliki kemampuan yang berbeda dalam menafsirkan suatu permasalahan.

Chan dan Leung (2006) menemukan bahwa ethical reasoning, tingkat idealisme, tingkat relativisme, prestasi akademik dan jenis kelamin tidak memiliki hubungan yang signifikan terhadap sensitivitas etis mahasiswa akuntansi. Namun pada variabel locus of control ditemukan memiliki hubungan yang signifikan terhadap sensitivitas etis. Selain itu pada penelitian mereka menunjukkan bahwa variabel usia memiliki hubungan positif dengan sensitivitas etis mahasiswa akuntansi.

Marwanto (2007) meneliti pengaruh pemikiran moral, tingkat idealisme, tingkat relativisme, locus of conrol, jenis kelamin, prestasi akademik, dan usia terhadap sensitivitas etis mahasiswa akuntansi. Hasil penelitian menunjukkan bahwa ethical reasoning, tingkat idealisme, tingkat relativisme, dan usia memiliki hubungan yang signifikan dengan sensitivitas etis mahasiswa akuntansi, sedangkan locus of control, prestasi akademik, dan 
jenis kelamin tidak memiliki hubungan signifikan dengan senstivitas etis mahasiswa akuntansi.

Wiyantoro dkk. (2011) meneliti pendekatan baru pengembangan etika profesi akuntan: anteseden perilaku moral mahasiswa akuntansi perspektif rest cognitive model. Hasil penelitian menunjukkan bahwa ethical reasoning dan tingkat idealisme memiliki hubungan yang signifikan terhadap sensitivitas etis mahasiswa akuntansi, sedangkan variabel locus of control, tingkat relativisme, usia, prestasi akademik dan jenis kelamin tidak memiliki hubungan signifikan dengan sensitivitas etis.

Sinaga (2015) meneliti pengaruh penalaran etis, orientasi etis, locus of control, gender dan usia terhadap sensitivitas etis mahasiswa akuntansi. Hasil penelitiannya menunjukkan bahwa tingkat idealisme, tingkat relativisme, usia dan jenis kelamin memiliki hubungan signifikan dengan sensitivitas etis mahasiswa akuntansi, sedangkan ethical reasoning dan locus of control ditemukan tidak memiliki hubungan yang signifikan dengan sensitivitas etis mahasiswa akuntansi.

Berkaitan dengan hasil penelitian sebelumnya yang belum konsisten mengenai faktorfaktor yang mempengaruhi sensitivitas etis mahasiswa akuntansi, maka peneliti tertarik untuk mereplikasi penelitian mengenai pengaruh ethical reasoning dan karakter personal (locus of control, tingkat idealisme, tingkat relativisme, usia, prestasi akademik dan jenis kelamin terhadap senstivitas etis dengan mengambil sampel mahasiswa akuntansi Universitas Katolik Soegijapranata dan menambah ukuran sampel yang lebih besar serta mengurangi terjadinya non respon bias seperti pada penelitian Chan dan Leung (2006) dengan menggunakan cara survei penyebaran kuesioner dengan mengumpulkan hasil responden secara langsung.

\section{TINJAUAN LITERATUR DAN PERUMUSAN HIPOTESIS}

\section{Teori Perkembangan Moral Individu}

Rest (1983) dalam Chan dan Leung (2006) mengembangkan sebuah model proses dasar psikologi yang membentuk kepribadian seseorang dalam pengambilan keputusan etis yang terdiri atas empat komponen. Keempat komponen tersebut adalah adalah: 1) Moral Sensitivity mengacu pada kesadaran akan dimensi moral suatu isu. Hal ini terbentuk melalui kesadaran akan kodek etik, peraturan atau undang-undang yang ada, serta interprestasi situasi kompleks melalui perspektif sosial. (2) Moral Judgment merupakan kemampuan seseorang membentuk penalaran logis terkait pengambilan keputusan moral. (3) Moral Motivation menyangkut pembentukkan identitas dan integritas nilai-nilai moral dengan nilai-nilai lainnya. (4) Moral Character merupakan implementasi nilai-nilai moral, sering digambarkan sebagai karakter moral atau keberanian moral.

\section{Sensitivitas Etis}

Sensitivitas etis mengacu pada kesadaran bagaimana tindakan seseorang dapat mempengaruhi orang lain. Sensitivitas etis juga meliputi perancangan skenario yang mungkin secara imanjinatif, mengetahui sebab akibat dari rangkaian kejadian, empati dan keterampilan pengambilan peran (Chan dan Leung, 2006). Sensitivitas etis merupakan kemampuan untuk menyadari nilai-nilai etika atau moral dalam suatu keputusan etis (Al-Fithrie, 2015). Sensitivitas etis menjadi dasar dalam memahami sifat dasar etika dari suatu keputusan (Shaub et al., 1993 dalam Asana, Suartana dan Rasmini, 2014). Proses keputusan etis dimulai ketika pembuat keputusan mengakui bahwa situasi tertentu akan mempengaruhi kesejahteraan orang lain, dan dengan demikian mengidentifikasi permasalahan etika (Muttaqin, 2014). 
Orientasi etika sebagai alternatif pola pikir seseorang dalam menyelesaikan dilema etika terbentuk dari dua karakteristik yaitu idealisme dan relativisme (Forsyth, 1980). Idealisme mengacu pada kerpercayaan individu mengenai konsekuensi tidak melanggar nilai-nilai moral. Sedangkan relativisme adalah suatu paham yang menolak keabsolutan nilai-nilai moral dalam mengarahkan perilaku etis (Falah, 2006). Forsyth (1980) mengkategorikan orientasi etika menjadi empat yaitu : (1) Situasionisme, (2) Absolutisme, (3) Subyektif dan (4) Eksepsionis.

\section{Ethical Reasoning dan Sensitivitas Etis}

Seseorang dikatakan bermoral jika memiliki kesadaran moral yaitu kemampuan menilai baik buruknya, boleh tidaknya, serta etis tidaknya suatu perbuatan. Ilham (2012) serta Setiono (1982) dalam Tarigan dan Ade Rahmawati (2013) mengungkapkan bahwa ethical reasoning lebih berkaitan dasar (alasan) seseorang melakukan suatu tindakan, yang selanjutnya akan dinilai apakah tindakan tersebut baik atau buruk. Ethical reasoning merupakan kesadaran moral, yang mana menjadi faktor utama dalam pengambilan keputusan (Al-Fithrie, 2015). Widari (2008) dan Sari (2010) mengatakan ethical reasoning sebagai kemampuan atau konsep dasar yang dimiliki individu untuk menganalisa masalah atau memutuskan masalah sosial-moral dalam situasi kompleks dengan melakukan penilaian terlebih dahulu terhadap nilai dan sosial mengenai tindakan apa yang akan dilakukannya.

Ethical reasoning adalah kemampuan seseorang untuk menilai baik buruknya suatu perilaku. Sensitivitas etis adalah kemampuan seseorang untuk menyadari nilai-nilai moral dalam pengambilan keputusan etis. Ketika seseorang ingin melakukan suatu tindakan ia akan berpikir untuk mempertimbangkan apakah tindakannya termasuk beretika atau bukan. Pada tahap tersebut, individu akan memiliki kepekaaan etis terhadap apa yang dialaminya. Arnorld dan Panemon (1991), Chan dan Leung (2006), Marwanto (2007) dan Wiyantoro dkk. (2011) menemukan bahwa ethical reasoning berpengaruh terhadap sensitivitas etis mahasiswa akuntansi.

Berdasarkan argumen dan dukungan empiris penelitian terdahulu, hubungan ethical reasoning dan sensitivtias etis dinyatakan dalam hipotesis berikut ini:

\section{H1 : Ethical reasoning berpengaruh terhadap sensitivitas etis}

\section{Tingkat Idealisme dan Sensitivitas Etis}

Orientasi etika merupakan kemampuan individu untuk mengevaluasi dan mempertimbangkan nilai etika dalam suatu kejadian (Forsyth, 1992 dalam Abdurrahman dan Yuliana, 2011). Orientasi etika dikelompokkan menjadi dua kategori yaitu idealisme dan relativisme. Idealisme adalah sikap individu yang mempercayai bahwa konsekuensi dari tindakan yang dilakukan tidak melanggar nilai-nilai moral (Falah, 2006). Ketika mereka berhadapan dengan persoalan etis, mereka akan memikirkan bagaimanakah dampak perbuatan mereka terhadap nilai-nilai moral. Mereka akan mengambil keputusan dan berperilaku tidak bertentangan dengan peraturan dan nilai-nilai moral. Relativisme adalah sikap individu yang menolak peraturan moral dalam bertingkah laku (Falah, 2006). Ketika mereka menghadapi situasi etis, mereka dapat menerima penjelasan dari berbagai perspektif tanpa mempertimbangkan nilai-nilai moral. Mereka akan tetap mempertahankan kebenaran dan kelogisan suatu argumen walaupun hal tersebut bertentangan dengan nilai-nilai moral.

Nurfaidah (2011) dan Aziza dan Salim (2008) memperoleh hasil bahwa orientasi etika berpengaruh signifikan terhadap sensitivitas etis. Hasil penelitian Chan dan Leung (2006), Falah (2006), Asana, Suartana, dan Rasimi (2014), Dewi, Ramantha dan Rasmini (2015), Sutiarsih, Herawati dan Sinarwati (2014) serta Martina, Werastuti dan Sujana (2015) menunjukkan hasil yang lebih detil terkait variabel orientasi etika bahwa tingkat idealisme 
mahasiswa akuntansi berhubungan positif dengan sensitivitas etis, sedangkan tingkat relativisme berhubungan negatif dengan sensitivitas etis.

Berdasarkan argumen dan dukungan empiris penelitian terdahulu, hubungan idealisme dan relatisme dengan sensitivitas etis dinyatakan dalam hipotesis berikut ini:

\section{$\mathbf{H}_{2 \mathrm{a}}$ : Tingkat idealisme berpengaruh positif terhadap sensitivitas etis}

$H_{2 b}$ : Tingkat relativisme berpengaruh negatif terhadap sensitivitas etis

\section{Locus of Control dan Sensitivitas Etis}

Locus of control adalah pandangan individu yang berkaitan dengan kegagalan dan keberhasilannya pada suatu aktivitas yang dipengaruhi oleh faktor internal dan eksternal. Locus of control internal adalah cara pandang individu mengenai segala sesuatu yang baik ataupun buruk yang diperoleh dipengaruhi oleh faktor internal seperti tindakan, perilaku dan kerja keras dari individu itu sendiri, sedangkan locus of control eksternal dipengaruhi oleh faktor luar misalnya keberuntungan, kesempatan dan takdir. Ketika individu dengan locus of control internal menghadapi situasi etis, mereka akan mampu berpikir dan mengendalikan diri dalam mengambil keputusan yang tidak bertentangan dengan norma moral. Sedangkan ketika individu dengan locus of control eksternal menghadapi situasi etis, mereka merasa tidak mampu mengendalikan diri mereka dan pasrah terhadap situasi yang ada. Jika mereka terlibat berperilaku tidak etis, mereka cenderung tidak bisa menolak untuk tidak berperilaku demikian.

Rotter (1966) mengemukakan bahwa locus of control merupakan cara pandang mengenai kemampuan pengendalian diri seseorang terhadap suatu peristiswa. Locus of control berkaitan dengan kepercayaan seseorang terhadap takdir, kepercayaan diri, dan usaha atau kerja keras pribadi. Hastuti (2007) menjelaskan bahwa seseorang dengan locus of control internal menyakini bahwa apa yang terjadi pada dirinya merupakan konsekuensi dari tindakan yang dia lakukan sendiri sedangkan seseorang dengan locus of control eksternal menyakini bahwa kejadian-kejadian yang terjadi dalam hidupnya dipengaruhi oleh takdir dan keberuntungan

Chan dan Leung (2006) memberi bukti locus of control berhubungan signifikan dengan sensitivitas etis. Locus of control internal yang berasal dari pengetahuan dan pemahaman mengenai etika menjadi dasar bagi seseorang untuk dapat lebih sensitif terhadap masalah-masalah etika dan lebih baik dalam pengambilan keputusan dibandingkan dengan locus of control eksternal. Berdasarkan argumen dan dukungan empiris penelitian terdahulu, hubungan locus of control dan sensitivitas etis dinyatakan dalam hipotesis berikut ini:

\section{H3 : Terdapat perbedaan sensitivitas etis antara locus of control internal dan locus of control eksternal}

\section{Usia dan Sensitivitas Etis}

Usia menunjukkan kematangan dalam menentukan pertimbangan moral. Individuindividu yang berusia lebih muda cenderung kurang peduli terhadap masalah-masalah etika daripada individu-individu yang berusia lebih tua (Combe dan Newmna, 1997 dalam Marwanto, 2007). Dengan usia yang lebih tua, individu akan lebih berhati-hati dalam mendeteksi suatu masalah dan pengambilan keputusan. Sebaliknya, individu yang berusia lebih muda, mereka akan lebih ceroboh dalam pengambilan keputusan. Hasil studi Chan dan Leung (2006), Marwanto (2007) dan Sinaga (2015) menunjukkan bahwa usia memiliki hubungan positif dengan sensitivitas etis.

Berdasarkan argumen dan dukungan empiris penelitian terdahulu, hubungan usia dan sensitivitas etis dinyatakan dalam hipotesis berikut ini:

H4 : Terdapat perbedaan sensitivitas etis yang berusia $\leq 20$ tahun dan $\geq 20,1$ tahun 


\section{Prestasi Akademik dan Sensitivitas Etis}

Prestasi akademik merupakan pencapaian yang diraih selama masa pendidikan. Seseorang yang memiliki prestasi akademik tinggi memiliki kemampuan yang baik terkait pemahaman nilai-nilai moral, sehingga ketika berada dalam situasi etis, mereka akan cenderung mampu membuat penalaran etis dengan mempertimbangkan keberadaan normanorma moral. Sebaliknya seseorang yang prestasi akademiknya rendah akan memiliki kemampuan yang buruk terkait pemahaman nilai-nilai moral sehingga apabila dihadapkan dalam suatu persoalan etis mereka cenderung akan membuat penalaran yang berkaitan dengan kepentingannya sendiri yang kemungkinan bisa bertentangan dengan nilai-nilai moral.

Penelitian Spickelmier (1983) dalam Shaub (1994) menjelaskan hubungan logis antara prestasi akademik dan moral reasoning, menjelaskan hubungan logis antara moral reasoning terhadap sensitivitas etis dan prestasi akademik terhadap sensitivitas etis. Penelitian Gumayal dan Rifa (2012) menunjukkan bahwa indeks prestasi kumulatif berpengaruh terhadap sensitivitas etis mahasiswa akuntansi.

Berdasarkan argumen dan dukungan empiris penelitian terdahulu, hubungan prestasi akademik dan sensitivitas etis dinyatakan dalam hipotesis berikut ini:

\section{H5 : Prestasi akademik berpengaruh terhadap sensitivitas etis}

\section{Gender dan Sensitivitas Etis}

Gender merupakan sifat pribadi yang membedakan antara laki-laki dan perempuan misalnya peran, perilaku, mentalitas dan karakteristik emosional. Laki-laki dikenal sebagai sosok yang agresif, bersikap cuek dan mengandalkan logika dalam berpikir apabila menghadapi suatu permasalahan. Berbeda dengan perempuan yang terkadang masih melibatkan unsur perasaan. Ketika seorang laki-laki dihadapkan pada situasi etis, mereka akan memiliki persepsi bahwa pencapaian prestasi atau pencapaian kesusksesan merupakan suatu persaingan sehingga mereka lebih cenderung untuk mengabaikan peraturan moral. Sedangkan ketika seorang perempuan dihadapkan pada situasi etis, mereka akan lebih memfokuskan untuk menjalankan tugas dengan baik dan menciptakan hubungan kerja yang harmonis sehingga mereka lebih patuh dan taat pada peraturan moral. Iswarini dan Mutmainah (2013), Sinaga (2015) dan Dewi, Sujana dan Purnamawati (2017) menunjukkan hasil penelitian bahwa jenis kelamin memiliki pengaruh yang signifikan terhadap sensitivitas etis. Berdasarkan argumen dan dukungan empiris penelitian terdahulu, hubungan gender dan sensitivitas etis dinyatakan dalam hipotesis berikut ini:

\section{H6 : Gender berpengaruh terhadap sensitivitas etis}

\section{METODA PENELITIAN}

\section{Sampel Penelitian}

Sampel penelitian adalah mahasiswa fakultas ekonomi dan bisnis jurusan akuntansi Unika Soegijapranta yang aktif pada tahun ajaran 2017/2018. Teknik pengambilan sampel yang digunakan pada penelitian ini adalah judgment sampling yaitu purposive sampling dengan cara mengambil sampel dari populasi berdasarkan kriteria tertentu (Hartono, 2013). Kriteria sampel yang digunakan dalam penelitian adalah sebagai berikut :

1. Mahasiswa Fakultas Ekonomi dan Bisnis jurusan Akuntansi yang aktif pada semester ganjil/genal di tahun ajaran 2017/2018

2. Mahasiswa Akuntansi yang telah menempuh matakuliah Pengauditan dan Etika Bisnis dan Profesi 
Jenis data yang digunakan dalam penelitian ini adalah data primer. Data primer merupakan sumber data yang diperoleh secara langsung dari sumber pertama atau tidak melalui perantara. Pengumpulan data menggunakan teknik survei dengan penyebaran kusioner kepada sumber data. Kuesioner yang dibagikan berupa pertanyaan atau pernyataan tertulis mengenai sensitivitas etis dan karakter personal (ethical reasoning, tingkat idealisme, tingkat relativisme, locus of control, usia, prestasi akademik dan jenis kelamin).

\section{Definisi Operasional dan Pengukuran Variabel Sensitivitas Etis}

Variabel dependen pada penelitian ini adalah sensitivitas etis. Sensitivitas etis merupakan persepsi responden mengenai kemampuan untuk menyadari nilai-nilai moral pada situasi atau konflik etis dalam pengambilan keputusan. Variabel sensitivitas etis diukur dengan 4 kasus yang dikutip dari Al-Fithrie (2015) dan menggunakan skala likert (Skor 1 Sangat Tidak Setuju - skor 5 Sangat Setuju). Keempat item pernyataan sensitivitas etis ini merupakan pernyataan recording. Semakin rendah skor yang diberikan responden menunjukkan semakin tinggi pula tingkat sensitivitas etis seseorang.

\section{Ethical reasoning}

Ethical reasoning merupakan persepsi responden mengenai seberapa mampu seseorang dapat menilai etis tidaknya suatu perbuatan. Ethical reasoning dalam penelitian ini diukur dengan menggunakan instrument dari Multidimensional Ethics Scale yang terdiri dari lima konstruk yaitu justice atau moral equity, relativism, egoism, utilitarianism dan deontologi atau contractual. Variabel ethical reasoning diukur dengan 12 pertanyaan yang dikutip dari Al-Fithrie (2015) dan menggunakan skala likert (Skor 1 Sangat Tidak Setuju - skor 5 Sangat Setuju). Semakin tinggi nilai skala yang diberikan oleh responden menunjukkan semakin tinggi ethical reasoning seseorang.

\section{Orientasi Etika}

Variabel orientasi etika di ukur dengan dua karakteristik yaitu idealisme dan relativisme yang terdiri dari 20 pertanyaan dan menggunakan skala likert (Skor 1 Sangat Tidak Setuju skor 5 Sangat Setuju) yang dikutip dari Falah (2006). Dalam penelitian ini, karakteristik pertama yaitu idealisme dibentuk oleh 10 pertanyaan (kuesioner 1 sampai 10) yang menunjukkan merupakan persepsi responden mengenai kepercayaan seseorang untuk tidak melakukan pelanggaran etika pada situasi konflik yang dihadapi. Semakin tinggi nilai skala yang diberikan responden menunjukkan semakin tinggi tingkat idealisme seseorang. Karakteristik kedua yaitu relativisme dibentuk oleh 10 pertanyaan (kuesioner 11 sampai 20) yang menunjukkan persepsi responden mengenai kepercayaan seseorang menolak peraturan moral. Semakin tinggi nilai skala yang diberikan oleh responden menunjukkan semakin tinggi tingkat relativisme seseorang.

\section{Locus of Control}

Locus of control merupakan persepsi responden mengenai kemampuan pengendalian seseorang terhadap suatu peristiwa. Variabel ini diukur dengan 23 pasangan item pernyataan dikutip dari Marwanto (2007) yang setiap pasangan dikategorikan pernyataan (a) sebagai internal dan pernyataan (b) sebagai eksternal. Pada penelitian ini variabel locus of control diukur sebagai variabel dummy yang menggunakan skor $0=$ locus of control internal dan $1=$ locus of control eksternal. 


\section{Usia, Indeks Prestasi Kumulatif, dan Gender}

Variabel usia dikelompokkan berdasarkan grade atau rentang usia yaitu $1=\leq 20$ tahun dan $2=\geq 20,1$ tahun. Indeks prestasi kumulatif dikelompokkan berdasarkan rentang nilai yaitu $1=0,00-2,99 ; 2=3,00-4,00$. Sementara gender diukur menggunakan variabel dummy, skor $0=$ perempuan dan $1=$ laki-laki.

\section{Uji Validitas}

Pengujian validitas menunjukkan seberapa nyata suatu pengujian mengukur apa yang seharusnya diukur. Kusioner dikatakan valid apabila pertanyaan atau pernyataan yang tercantum dalam kuesioner mampu mengungkapkan sesuatu yang akan diukur oleh kuesioner tersebut. Uji validitas data penelitian dilakukan dengan koefisien korelasi Product Moment Person dengan model Cronbach Alpha. Jika nilai Cronbach Alpha If Item Deleted yang lebih kecil dari nilai Cronbach Alpha Instrumen dan bernilai positif maka pertanyaan atau indikator yang terdapat pada kuesioner dikatakan valid (Murniati dkk., 2013).

\section{Uji Reliabilitas}

Pengujian reliabilitas menunjukkan akurasi dan ketepatan dari pengukurannya. Reliabilitas berhubungan dengan akurasi dan konsistensi dari pengukurnya. Suatu kuesioner dapat dikatakan reliable atau handal apabila tanggapan seseorang terhadap kuesioner tersebut tetap konsisten dari waktu ke waktu. Dikatakan konsisten jika beberapa pengukuran terhadap subyek yang sama diperoleh hasil yang tidak berbeda (Hartono, 2013). Variabel dapat dikatakan reliabel apabila memiliki nilai cronbach alpha lebih dari 0,6.

\section{Uji Asumsi Klasik}

Uji Asumsi klasik dilakukan sebelum melakukan pengujian hipotesis. Pengujian asumsi klasik bertujuan untuk membuktikan bahwa data yang diteliti terlepas dari gejala asumsi klasik. Asumsi klasik yang digunakan dalam penelitian ini adalah sebagai berikut :

\section{Uji Normalitas}

Uji normalitas digunakan untuk menguji apakah sampel penelitian merupakan jenis distribusi normal. Uji normalitas dalam penelitian ini menggunakan pengujian Kolmonogrov - Smirnov. Data penelitian akan dinyatakan berdistribusi normal apabila nilai Asymp. Sig lebih besar dari 0,05 dan sebaliknya data penelitian akan dinyatakan tidak normal apabila nilai Asymp. Sig yang lebih kecil dari 0,05 (Ghozali, 2011).

\section{Uji Heterokedastisitas}

Uji heteroskedastisitas bertujuan untuk menguji apakah dalam model regresi terjadi ketidaksamaan varian dan residual dari pengamat. Model regresi yang baik adalah homokedastisitas atau tidak terjadi heteroskedastisitas. Pengujian ini menggunakan uji Glejser yaitu dengan meregresikan variabel terhadap nilai absolut residual. Kriteria data yang terlepas dari heteroskedastisitas memiliki nilai signifikan lebih besar 0,05. Sedangkan data yang mengandung heteroskedastisitas memiliki nilai signifikan lebih kecil dari 0,05 (Ghozali, 2011).

\section{Uji Multikolineritas}

Uji multikolineritas digunakan untuk menguji korelasi antar variabel yang diuji dalam model dengan variabel bebas. Uji multikolineritas pada penelitian ini menggunakan variance inflation factor (VIF) dan toleransi. Model regresi yang bebas dari masalah multikolineritas memiliki nilai VIF $<10$ dan nilai toleransi $>0,1$. Apabila persentase korelasi dibawah 90\% maka dapat dikatakan tidak terjadi multikolineritas yang serius (Ghozali, 2011). 


\section{Uji regresi Berganda}

Untuk memperoleh bukti empiris dari setiap hipotesis, dilakukan pengujian regresi berganda. Berikut merupakan model empiris penelitian :

$$
S E=a+b_{1} E R+b_{2} I+b_{3} R+b_{4} L o c I+b_{5} L o c E+b_{6} U+b_{7} I P K+b_{8} J K+e
$$

Keterangan :

$\begin{array}{ll}\text { SE } & : \text { Sensitivitas Etis } \\ \text { ER } & : \text { Ethical reasoning } \\ \text { I } & : \text { Idealisme } \\ \text { R } & : \text { Relativisme } \\ \text { LocI } & : \text { Locus of Control Internal } \\ \text { LocE } & : \text { Locus of Control Eksternal } \\ \text { U } & : \text { Usia } \\ \text { IPK } & : \text { Indeks Prestasi Kumulatif } \\ \text { JK } & : \text { Jenis Kelamin }\end{array}$

\section{Uji Beda}

Uji beda t-test merupakan pengujian yang digunakan untuk menentukan apakah dua sampel yang tidak berhubungan memiliki nilai rata-rata yang berbeda. Pengujian yang dilakukan adalah independent - sample test. Pengujian ini dilakukan untuk mengetahui perbedaan rata-rata dua populasi atau kelompok independen. Jika independen maka tidak terdapat hubungan antara kedua kelompok sampel yang akan diuji tersebut (subyeknya berbeda). Cara pengambilan keputusan hipotesis dalam pengujian dilihat dari thitung dan ttabel. Jika thitung > ttabel maka hipotesis diterima sebaliknya jika thitung < ttabel maka hipotesis ditolak.

\section{HASIL DAN PEMBAHASAN}

Peneliti membagikan kuesioner kepada mahasiswa jurusan akuntansi Universitas Katolik Soegijapranata Semarang. Proses penyebaran kuesioner pada penelitian ini dapat dilihat secara lengkap di tabel 1.

Tabel 1. Proses Penyebaran Kuesioner

\begin{tabular}{|l|l|}
\hline Keterangan & Jumlah \\
\hline Jumlah kuesioner yang dibagikan & 207 \\
\hline Jumlah kuesioner yang tidak lengkap & $(27)$ \\
\hline Jumlah kuesioner yang memenuhi kriteria & 180 \\
\hline
\end{tabular}

\section{Gambaran Umum Responden}

Berdasarkan Tabel 2, gambaran umum identitas responden, sebagian besar responden penelitian berjenis kelamin perempuan yaitu sebanyak 101 orang sedangkan responden lakilaki sebanyak 79 orang. Hal ini menunjukkan bahwa responden dalam penelitian ini didominasi oleh perempuan.

Dilihat dari segi usia, sebagian besar responden berusia $\geq 20,1$ tahun yaitu sebanyak 176 orang sedangkan responden yang berusia $\leq 20$ tahun sebanyak 4 orang. Ini berarti 
mayoritas responden penelitian berusia $\geq 20,1$ tahun. Mereka merupakan mahasiswa semester 6 ke atas dan beberapa dari mereka sudah mengambil skripsi. Ditinjau dari indeks prestasi kumulatif, sebagian besar responden memiliki indeks prestasi kumulatif antara 0,00-2,99 yaitu sebanyak 90 orang dan yang berindeks prestasi kumulatif 3,00-4,00 sebanyak 90 orang. Artinya, indeks prestasi kumulatif responden dalam penelitian ini cukup baik.

Tabel 2. Gambaran Umum Identitas Responden

\begin{tabular}{|l|l|l|}
\hline No & Keterangan & Jumlah \\
\hline 1. & Jenis Kelamin & \\
\hline \multirow{2}{*}{2.} & Perempuan & 101 \\
\cline { 2 - 3 } & Laki-laki & 79 \\
\hline \multirow{2}{*}{2} & Usia Responden & \\
\cline { 2 - 3 } & $\leq 20$ tahun & 4 \\
\hline 3 & Indeks Prestasi Kumulatif Responden & 176 \\
\hline & $0,00-2,99$ & 90 \\
\hline & $3,00-4,00$ & 90 \\
\hline
\end{tabular}

\section{Uji Validitas dan Reliabilitas}

Pengujian validitas dan reliablitas dilakukan pada variabel sensitivitas etis, ethical reasoning, idealisme, relativisme dan locus of control. Pada tahap pengujian ini data sampel telah memenuhi kriteria valid dan reliabel.

\section{Statistik Deskriptif}

Tabel 3 menampilkan hasil compare means yang menggambarkan statistik deskriptif pada penelitian ini. Dilihat dari gender, mahasiswa perempuan memiliki tingkat sensitivitas etis sedikit di atas mahasiswa laki-laki. Sedangkan nilai rata-rata persepsi mahasiswa yang

Tabel 3. Hasil Compare Means

\begin{tabular}{|l|l|l|l|l|l|}
\hline Keterangan & Jumlah & SE & ER & ID & RE \\
\hline Gender: & & & & & \\
\hline Perempuan & 101 & 3,4851 & 4,2222 & 4,1002 & 3,5215 \\
\hline Laki-laki & 79 & 3,3766 & 4,2419 & 4,1551 & 3,5232 \\
\hline Sig. & & 0,436 & 0,797 & 0,415 & 0,981 \\
\hline Usia : & & & & & \\
\hline$\leq 20$ tahun & 4 & 2,8750 & 4,1112 & 4,1250 & 3,5000 \\
\hline$\geq 20,1$ tahun & 176 & 3,4503 & 4,2335 & 4,1243 & 3,5227 \\
\hline Sig. & & 0,220 & 0,636 & 0,997 & 0,928 \\
\hline $\begin{array}{l}\text { Indeks Prestasi } \\
\text { Kumulatif : }\end{array}$ & & & & & \\
\hline $0,00-2,99$ & 90 & 3,4583 & 4,2012 & 4,1222 & 3,4790 \\
\hline $3,00-4,00$ & 90 & 3,4167 & 4,2604 & 4,1264 & 3,5655 \\
\hline Sig. & & 0,764 & 0,436 & 0,950 & 0,245 \\
\hline
\end{tabular}


berjenis kelamin perempuan dan laki-laki mengenai ethical reasoning, idealisme dan relativisme, hampir sama. Kemudian dilihat dari nilai signifikannya, tidak ada perbedaan yang signifikan berkaitan dengan sensitivitas etis, ethical reasoning, idealisme dan relativisme di antara mahasiswa perempuan dan laki-laki.

Ditinjau dari usia, nilai rata-rata sensitivitas etis mahasiswa yang berusia $\leq 20$ tahun lebih rendah dibandingkan dengan yang berusia $\geq 20,1$ tahun sedangkan nilai ethical reasoning, idealisme dan relativisme memiliki nilai rata-rata yang hampir sama baik mahasiwa yang berusia $\leq 20$ tahun dan yang berusia $\geq 20,1$ tahun. Dilihat dari nilai signifikan yang disajikan pada Tabel 3 menunjukkan bahwa variabel sensitivitas etis, ethical reasoning, idealisme dan relativisme memiliki nilai signifikan yang lebih besar dari 0,05 sehingga dapat disimpulkan bahwa baik mahasiswa yang berusia $\leq 20$ tahun dan yang berusia $\geq 20,1$ tahun tidak memiliki perbedaan yang signifikan pada variabel yang terkait.

Berdasarkan kategori indeks prestasi kumulatif pada tabel 3 nilai rata-rata tingkat sensitivitas etis, ethical reasoning, idealisme dan relativisme antara mahasiswa yang memiliki indeks prestasi kumulatif 0,00 - 2,99 dan yang memiliki indeks prestasi kumulatif 3,00-4,00 adalah hampir sama. Kemudian dari nilai signifikan pada semua variabel menunjukkan nilai yang lebih besar dari 0,05 sehingga dapat disimpulkan bahwa tidak terdapat perbedaan antara mahasiswa yang berindeks prestasi $0,00-2,99$ dan 3,00-4,00 dengan tingkat sensitivitas etis, ethical reasoning, idealisme dan relativisme.

\section{Uji Asumsi Klasik}

Setelah melakukan pengujian validitas dan reliabilitas untuk masing-masing variabel, peneliti selanjutnya melakukan uji asumsi klasik. Uji asumsi klasik yang digunakan dalam penelitian ini adalah Uji normalitas, uji heterokedastisitas dan uji multikolineritas. Pada tahap uji asumsi klasik ini data sampel penelitian telah bebas dari uji asumsi klasik.

\section{Uji Hipotesis}

Setelah melakukan uji asumsi klasik, peneliti melakukan uji hipotesis. Pengujian hipotesis pada penelitian ini menggunakan regresi berganda. Namun untuk pengujian hipotesis variabel locus of control, jenis kelamin, usia, dan indeks prestasi kumulatif menggunakan uji beda. Berikut ini disajikan tabel hasil uji hipotesis di tabel 4 dan hasil uji beda di tabel 5 .

Berdasarkan tabel 4, nilai t-hitung untuk variabel ethical reasoning adalah 2,466, sedangkan nilai t-tabel untuk pengujian dua sisi dengan tingkat signifikan $10 \%$ adalah 1,96, artinya ethical reasoning berpengaruh signifikan terhadap sensitivitas etis pada tingkat keyakinan $90 \%$ atau dapat dikatakan bahwa hasil regresi hipotesis 1 diterima, yaitu ethical reasoning berpengaruh terhadap sensitivitas etis.

Tabel 4. Hasil Uji Regresi

\begin{tabular}{|l|l|l|l|l|}
\hline Model & Koefisien & T & Sig. & Hasil \\
\hline ER $\rightarrow$ SE & 0,319 & 2,466 & 0,015 & Diterima \\
\hline ID $\rightarrow$ SE & 0,435 & 2,939 & 0,004 & Diterima \\
\hline RE $\rightarrow$ SE & $-0,404$ & $-3,063$ & 0,003 & Diterima \\
\hline
\end{tabular}

Berdasarkan tabel 4, nilai t-hitung untuk variabel idealisme sebesar 2,939, sedangkan nilai t-tabel untuk pengujian satu sisi dengan tingkat signifikansi $10 \%$ adalah 1,645 . Hal ini berarti idealisme berpengaruh positif signifikan terhadap sensitivitas etis pada tingkat keyakinan $90 \%$ atau dikatakan bahwa hasil regresi hipotesis 2a diterima, yaitu idealisme berpengaruh positif terhadap sensitivitas etis. 
Dilihat dari tabel 4, variabel relativisme memiliki nilai t-hitung sebesar -3,063 dan nilai t-tabel untuk pengujian satu sisi dengan tingkat signifikan $10 \%$ sebesar 1,645 . Ini menunjukkan bahwa terdapat pengaruh negatif signifikan relativisme terhadap sensitivitas etis pada tingkat keyakinan $90 \%$ sehingga dapat disimpulkan bahwa hasil regresi hipotesis $2 \mathrm{~b}$ diterima, yaitu relativisme berpengaruh negatif terhadap sensitivitas etis.

Berdasarkan Tabel 5, masing-masing nilai t-hitung untuk variabel locus of control, jenis kelamin, usia $-0,256,0,780$ dan -1,231 dan nilai F-hitung indeks prestasi akademik adalah sebesar 0,416 sedangkan nilai t-tabel untuk pengujian dua sisi dengan tingkat signifikan $10 \%$ adalah 1,96. Nilai t-hitung yang lebih kecil dari t-tabel menunjukkan bahwa hipotesis 3, 4, 5, dan 6 tidak berpengaruh signifikan pada tingkat keyakinan 90\% sehingga dapat disimpulkan hipotesis hipotesis tersebut ditolak yaitu tidak terdapat perbedaan sensitivitas etis antara responden yang memiliki locus of control internal maupun locus of control eksternal (H3), usia tidak berpengaruh terhadap sensitivitas etis (H4), indeks prestasi kumulatif tidak berpengaruh terhadap sensitivitas etis (H5) dan jenis kelamin tidak berpengaruh terhadap sensivitas etis (H6).

Tabel 5. Hasil Uji Beda

\begin{tabular}{|l|l|l|l|}
\hline Model & T & Sig. & Keterangan \\
\hline Independent Sample T Test & & & \\
\hline LOC $\rightarrow$ SE & $-0,256$ & 0,799 & Ditolak \\
\hline GEN $\rightarrow$ SE & 0,780 & 0,436 & Ditolak \\
\hline DU $\rightarrow$ SE & $-1,231$ & 0,220 & Ditolak \\
\hline DIPK $\rightarrow$ SE & 0,301 & 0,764 & Ditolak \\
\hline
\end{tabular}

\section{Pembahasan}

\section{Hubungan antara Ethical Reasoning dengan Sensitivitas Etis}

Berdasarkan hasil pengujian hipotesis pada tabel 4 , ethical reasoning berpengaruh terhadap sensitivitas etis dengan tingkat signifikansi 0,015. Ethical reasoning merupakan persepsi mahasiswa mengenai seberapa mampu seseorang dapat menilai etis tidaknya suatu perbuatan. Sedangkan sensitivitas etis merupakan persepsi responden mengenai kemampuan untuk menyadari nilai-nilai moral dalam mengambil keputusan pada situasi etika. Apabila seseorang ingin melakukan suatu tindakan ia akan berpikir untuk mempertimbangkan apakah tindakannya merupakan tindakan etis atau tidak sehingga pada saat bersamaan ia pun memiliki kepekaan etis terhadap situasi tersebut. Dalam penelitian ini, koefisien variabel ethical reasoning bernilai positif, yang menunjukkan bahwa semakin tinggi ethical reasoning mahasiswa akuntansi, semakin tinggi pula sensitivitas etis mahasiswa tersebut. Hasil penelitian ini konsisten dengan hasil penelitian Arnold dan Panemon (1991), Chan dan Leung (2006) dan Wiyantoro dkk. (2011).

\section{Tingkat Idealisme dan Sensitivitas Etis}

Hasil pengujian hipotesis yang tersaji di tabel 4 menunjukkan bahwa idealisme berpengaruh positif terhadap sensitivitas etis dengan tingkat signifikasi 0,004. Idealisme merupakan persepsi mahasiswa yang percaya dan menyakini bahwa tindakan apapun yang dilakukan itu merupakan tindakan yang tidak melanggar nilai-nilai moral. Individu yang tergolong bersikap idealis akan memikirkan bagaimanakah dampak perbuatan mereka terhadap nilai-nilai moral sehingga dalam pengambilan suatu keputusan etis mereka akan berperilaku tidak bertentangan dengan peraturan dan nilai-nilai moral. Menurut hasil tabel 4, koefisien variabel idealisme bernilai positif, artinya semakin tinggi tingkat idealisme 
mahasiswa akuntansi maka semakin tinggi juga sensitivitas etis mahasiswa tersebut. Hasil penelitian ini sesuai dengan penelitian Chan dan Leung (2006), Falah (2006) serta Dewi, Ramantha dan Rasmini (2015).

Dilihat dari penyajian hasil pengujian hipotesis pada tabel 4 menunjukkan bahwa relativisme berpengaruh negatif terhadap sensitivitas etis dengan tingkat signifikansi 0,003 . Relativisme merupakan persepsi mahasiswa mengenai kepercayaan seseorang menolak peraturan moral dalam bertingkah laku. Bagi mereka situasi etis yang dialami itu dapat ditoleransi dan mereka tetap bisa menerima dan berpegang pada kebenaran dan kelogisan suatu argumen meskipun bertentangan dengan nilai-nilai moral. Dengan demikian mahasiswa yang relativis cenderung memiliki sensivitas yang rendah. Hal ini dibuktikan pada nilai thitung yang disajikan pada tabel 4 yaitu -3,063, artinya semakin tinggi relativisme mahasiswa akuntansi maka sensitivitas etis mahasiswa akuntansi semakin rendah. Hasil penelitian ini sama dengan penelitian Chan dan Leung (2006), Falah (2006) serta Dewi, Ramantha dan Rasmini (2015).

\section{Hubungan antara Locus of Control dan Sensitivitas Etis}

Dari hasil pengujian hipotesis pada Tabel 5 menunjukkan bahwa tidak terdapat perbedaan sensitivitas etis mahasiswa akuntansi dengan locus of control internal dan locus of control eksternal. Locus of control dikategorikan menjadi dua yaitu locus of control internal adalah mereka yang percaya bahwa hasil yang diperoleh merupakan usaha dan kerja keras pribadi sedangkan locus of control eksternal adalah mereka yang percaya bahwa keberhasilan yang diperoleh merupakan keberuntungan.

Dari kedua kategori locus of control ini tidak memiliki perbedaan sensitivitas etis, yang mana ditunjukkan pada nilai signifikannya yaitu sebesar 0,779 (lebih besar dari 0,025). Hal ini berarti ketika mahasiswa akuntansi yang tergolong dalam locus of control internal dihadapkan pada suatu permasalahan etis, mereka tidak akan selalu bisa mampu berpikir dan mengendalikan diri dalam keputusan yang tidak bertentangan dengan norma moral dan juga sebaliknya ketika mahasiswa akuntansi yang tergolong dalam locus of control eksternal menghadapi suatu situasi etis, mereka tidak selalu berperilaku tidak etis, sehingga dapat dikatakan bahwa baik locus of control internal maupun locus of control eksternal tidak memiliki perbedaan terhadap sensitivitas etis. Tidak adanya perbedaan ini menunjukkan karena adanya suatu pilihan tindakan yang baik (tepat) tidak secara langsung dipengaruhi atau ditentukan oleh pusat kontrol diri (locus of control), tetapi ditentukan oleh keutamaan karakter individu, yaitu individu yang memiliki keutamaan moral dan kecerdasan emosional (Midyarany, 2016). Hasil penelitian ini konsisten dengan penelitian Marwanto (2007), Wiyantoro dkk. (2011) dan Sinaga (2015).

\section{Hubungan antara Usia dengan Sensitivitas Etis}

Berdasarkan hasil pengujian hipotesis yang tersaji pada tabel 5, menunjukkan bahwa usia tidak berpengaruh terhadap sensitivitas etis. Keputusan etis mahasiswa akuntansi tidak terlihat dari seberapa banyak usia mereka. Ketika berada dalam situasi etis mahasiswa akuntansi berusia kurang dari 20 tahun tidak selamanya bersikap ceroboh atau tidak berhatihati dalam pengambilan keputusan, juga sebaliknya. Dengan demikian usia tidak memiliki pengaruh terhadap sensitivitas etis ditunjukkan pada nilai signifikan sebesar 0,220 yang tersaji dalam Tabel 5. Dalam penelitian ini, usia terbukti tidak berpengaruh terhadap sensitivitas etis mahasiswa akuntansi. Kemungkinan penyebabnya karena perbedaan kategori usia yang berdekatan, yaitu kelompok usia $\leq 20$ tahun dan $\geq 20$ tahun. Usia responden yang relatif sama memungkinkan mereka memiliki pemikiran logis yang sama. Hasil penelitian ini konsisten dengan penelitian Wiyantoro dkk. (2011) dan Iswarini dan Mutmainah (2012). 


\section{Hubungan antara Prestasi Akademik dan Sensitivitas Etis}

Menurut hasil pengujian hipotesis pada tabel 4.19, menunjukkan bahwa tidak terdapat pengaruh indeks prestasi kumulatif terhadap sensitivitas etis. Prestasi akademik bukanlah salah satu faktor yang dapat mempengaruhi sensitivitas etis seseorang. Mahasiswa akuntansi yang memiliki prestasi akademik yang baik belum tentu memiliki wawasan dan pemahaman nilai-nilai moral serta penalaran yang baik pula ketika dihadapi dalam situasi etis, begitu juga sebaliknya. Sesuai dengan Tabel 5, nilai signifikan indeks prestasi akademik lebih besar dari 0,025 yaitu 0,764, artinya indeks prestasi kumulatif tidak berpengaruh terhadap sensitivitas etis. Tidak adanya perbedaan ini kemungkinan disebabkan karena indeks prestasi kumulatif berhubungan dengan bidang akademik dan bukan untuk menilai perilaku etis seseorang. Hasil penelitian ini sama dengan hasil penelitian Chan dan Leung (2006), Marwanto (2007), Wiyantoro dkk. (2011) dan Iswarini dan Mutmainah (2012).

\section{Hubungan antara Gender dan Sensitivitas Etis}

Hasil pengujian hipotesis pada tabel 5 menunjukkan bahwa tidak terdapat pengaruh jenis kelamin terhadap sensitivitas etis. Kepekaan seseorang terhadap suatu konflik etis tidak terlihat dari perbedaan jenis kelamin. Laki-laki tidak selamanya mengabaikan peraturan moral dan tidak selalu berpikir bahwa yang dilakukan adalah hal yang benar tanpa melihat pandangan orang lain. Begitu juga dengan anggapan bahwa perempuan selalu menaati peraturan dan melakukan tindakan secara hati-hati dalam pengambilan keputusan adalah tidak selalu benar, dalam artian anggapan ini bisa saja berlawanan. Perempuan tidak selalu memiliki tingkat kepekaan yang tinggi sebaliknya laki-laki pun tidak selalu memiliki tingkat kepekaan yang rendah. Berdasarkan tabel 5 disajikan nilai signifikan jenis kelamin lebih besar dari 0,025 yaitu 0,436, sehingga dapat dikatakan bahwa jenis kelamin tidak berpengaruh terhadap sensitivitas etis. Hal ini kemungkinan disebabkan oleh penyebaran kuesioner yang tidak merata pada responden perempuan dan laki-laki. Hasil penelitian ini sesuai hasil dengan penelitian Chan dan Leung (2006), Marwanto (2007) dan Wiyantoro dkk (2011).

\section{KESIMPULAN DAN SARAN}

Penelitian ini bertujuan untuk menguji pengaruh ethical reasoning dan karakter personal (orientasi etika, locus of control, usia, indeks prestasi kumulatif dan jenis kelamin) terhadap sensitivitas etis mahasiswa akuntansi. Berdasarkan penelitian ini didapatkan kesimpulan sebagai berikut :

1. Ethical reasoning berpengaruh terhadap sensitivitas etis mahasiswa akuntansi.

2. Tingkat idealisme berpengaruh positif terhadap sensitivitas etis mahasiswa akuntansi dan tingkat relativisme berpengaruh negatif terhadap sensitivitas etis mahasiswa akuntansi.

3. Tidak terdapat perbedaan sensitivitas etis mahasiswa akuntansi dengan locus of control internal dan locus of control eksternal.

4. Usia tidak berpengaruh terhadap sensitivitas etis mahasiswa akuntansi.

5. Indeks prestasi kumulatif tidak berpengaruh terhadap sensitivitas etis mahasiswa akuntansi.

6. Jenis kelamin tidak berpengaruh terhadap sensitivitas etis mahasiswa akuntansi 


\section{Saran}

Saran dalam penelitian ini adalah sebagai berikut :

1. Menambah jumlah sampel dengan melakukan penelitian di beberapa perguruan tinggi.

2. Melakukan penyebaran kuesioner secara merata pada kategori jenis kelamin, usia dan indeks prestasi

3. Memasukan kasus-kasus etis dalam pembahasan matakuliah akuntansi.

\section{DAFTAR PUSTAKA}

Abdurrahman dan Nur L. Yuliani. 2011. Determinasi Pengambilan Keputusan Etis Auditor Internal (Studi Empiris pada BUMN dan BUMD di Magelang dan Temanggung). Widya Warta. No. 2. Juli 2011.

Agoes, S. dan I. C. Ardana. 2014. Etika Bisnis dan Profesi: Tantangan Membangun Manusia Seutuhnya. Penerbit Salemba Empat. Jakarta. Edisi Revisi.

Al-Fithrie, N. L. 2015. Pengaruh Moral Reasoning dan Ethical Sensitivity terhadap Persepsi Etis Mahasiswa Akuntansi dengan Gender sebagai Variabel Moderasi (Studi Kasus pada Mahasiswa Akuntansi UNY). Skripsi. Universitas Negeri Yogyakarta.

Allen, P.W. and C. K. Ng. 2001. Self Interest Among CPAs May Influence their Moral Reasoning. Journal of Business Ethics. Vol. 33 No. 1, pp. 29-35.

Asana, G. H. S., I W. Suartana dan N. K. Rasmini. 2014. Pengaruh Pengalaman, Komitmen dan Orientasi Etika pada Sensitivitas Etika Auditor. Tesis. E-Jurnal Ekonomi dan Bisnis. Universitas Udayana.

Aziza, N. dan H. A. A. Salim. 2008. Pengaruh Orientasi Etika pada Komitmen dan Sensitivitas Etika Auditor (Studi Empiris pada Auditor di Bengkulu dan Sumatera Selatan). Simposius Nasional Akuntansi XI. Pontianak.

Bertens, Kees. 1993. Etika. Gramedia Pustaka Utama. Jakarta.

Buchan, H. F. 2005. Ethical Decision Making in the Public Accounting Profession: An Extension of Ajzen's Theory of Planned Behavior. Journal of Business Ethics. Vol. 6, pp. $165-81$.

Chan, A. S. 2012. Analisis Faktor-Faktor yang Mempengaruhi Pemilihan Karir Menjadi Akuntan Publik oleh Mahasiswa Jurusan Akuntansi. Jurnal Ilmiah Mahasiswa Akuntansi. Vol. 1 No. 1. Januari 2012.

Chan, S. Y.S. and L. Philomena. 2006. The Effect of Accounting Student's Ethical Reasoning and Personel Factors on their Ethical Sensitivity. Managerial Auditing Journal 21 (4): 436-457.

Chiu, R.K. 2003. Ethical Judgment and Whistle Blowing Intention: Examining the Moderating Role of Locus of Control. Journal of Business Ethics 30 (4): 2319-2336.

Cohen, J. R., L. W. Pant and D. J. Sharp. 2001. An Examination of Differences in Ethical Decision-Making Between Canadian Business Students and Accounting Professionals. Journal of Business Ethics 30 (4): 319-36.

Comunale, C.L., Sexton, T.R, and S.C Gara. 2006. Profesional Ethical Crises: A Case Study of Accounting Majors. Managerial Auditing Journal. Vol. 21 No. 6, pp. 636-656. 
Dewi, K. L.R., E. Sujana dan I G.A. Purnamawati. 2017. Pengaruh Budaya Etis Organisasi, orientasi Etika, dan Gender terhadap Sensitivitas Etika Auditor pada Inspektorat Pemerintah Kabupaten Bangli, Gianyar dan Klungkung. E-Journal S1 Akuntansi Universitas Pendidikan Ganesha 7 (1).

Elias, R. Z. 2002. Determinants of Earnings Management Ethics Among Accountants. Journal of Business Ethics 40 (1): 33-45.

Falah, S. 2006. Pengaruh Budaya Etis Organisasi dan Orientasi Etika terhadap Sensitivitas Etika (Studi Empiris Tentang Pemeriksaan Internal di Bawasda Pemda Papua). Tesis. Universitas Diponegoro. Semarang

Febrianty. 2010. Pengaruh Gender, Locus of Control, Intellectual Capital dan Ethical Sensitivity terhadap Perilaku Etis Mahasiswa Akuntansi pada Perguruan Tinggi. Jurnal Ilmiah Orasi Bisnis. Edisi Keempat.

Forsyth, D.R. 1980. A Taxonomy of Ethical Ideologies. Journal of Personality and Social Psychology. Vol. 39, pp. 175-84. Ghozali, Imam. 2011. Aplikasi Analisis Multivariate dengan Program IBM SPSS 19. Universitas Diponegoro. Semarang. Edisi Kelima.

Gul, F.A., Andy Y. Ng and Marian Y. J. W. Tong. 2003. Chinese Auditor' Ethical Behavior in an Audit Conflict Situation. Journal of Business Ethics 42 (4): 379-92.

Gumayal, R. E. dan D. Rifa. 2012. Pendekatan Baru Pengembangan Etika Profesi Akuntan: Anteseden Perilaku Moral Mahasiswa Akuntansi Perspektif Rest Cognitive Model. Jurnal Kajian Akuntansi dan Auditing 7 (2).

Hartono, J. 2013. Metodologi Penelitian Bisnis: Salah Kaprah dan Pengalaman-Pengalaman. BPFE. Yogyakarta, Edisi Keenam.

Hastuti, E. S. 2007. Perilaku Etis Mahasiswa dan Dosen Ditinjau dari Faktor Individual Gender dan Locus of Control. Jurnal Riset Ekonomi dan Bisnis 7 (1).

Ilham, T. W. 2012. Hubungan Antara Tingkat Penalaran Moral dengan Kedisplinan Siswa SMKN I Sragen. Skripsi. Universitas Muhammadiyah. Surakarta.

Iswarini, E. M. dan S. Mutmainah. 2013. Pengaruh Penalaran Etis dan Faktor-Faktor Pribadi Terhadap Sensitivitas Etis pada Mahasiswa Akuntansi. Diponegoro Jounral of Accounting, Vol. 1 No. 1. 2012.

Johan, R. 2002. Kepuasan Kerja Karyawan dalam Lingkungan Institusi Pendidikan. Jurnal Pendidikan Penabur. No. 1/ Th I, 1-19.

Kamus Besar Bahasa Indonesia. 1999. Departemen Pendidikan dan Kebudayaan. Balai Pustaka.

Karcher, J. N. 1996. Auditor's Ability to Discern the Presence of Ethical Problems. Journal of Business Ethics 15 (10): 1033-50.

Kohlberg, L. 1995. Tahap-tahap Perkembangan Moral (Alih bahasa John de Santo dan Agus Cremers SVD). Kanisiua. Yogyakarta.

Kustono, A. S. 2011. Pengaruh Jender dan Lokus Kendali terhadap Kinerja Karyawan Perguruan Tinggi. Media Riset Akuntansi 1 (1).

Mardawati, R. dan M. N. Aisyah. 2016. Pengaruh Orientasi Etis, Gender, dan Pengetahuan Etika terhadap Persepsi Mahasiswa Akuntansi Atas Perilaku Tidak Etis Akuntan. Jurnal Profia Edisi 6. Universitas Negeri Yogjayakarta. 
Martina, M. B., D. M. Werastuti dan E. Sujana. 2015. Pengaruh Budaya Etis Organisasi, Orientasi Etika, Pengalaman, dan Profesionalisme terhadap Sensitivtas Etika Kegiatan Audit yang Dilaksanakan Inspektorat Pemerintah Kabupaten Buleleng. Jurnal Akuntansi S1 3 (1).

Marwanto. 2007. Pengaruh Pemikiran Moral, Tingkat Idealisme, Tingkat Relativisme dan Locus of Control terhadap Sensitivitas, Pertimbangan, Motivasi dan Karakter Mahasiswa Akuntansi (Studi Eksperimen Pada Politeknik Negeri Samarinda). Tesis. Universitas Diponegoro. Semarang.

Mele, D. 2005. Ethical Education in Accounting: Integrating Rules, Value dan Virtues. Journal of Business Ethics 57 (1): 97-109.

Midyarany, D. 2016. Pengaruh Sensitivitas Etis, Gender, dan Locus of Control terhadap Perilaku Etis Mahasiswa. Skripsi. Sekolah Tinggi Ilmu Ekonomi Indonesia. Surabaya.

Molyneaux, D. 2004. After Andersen: An Experience of Integrating Ethics into Undergraduate Accountancy Education. Journal of Business Ethics. Vol. 54 No. 4, pp. 385-98.

Muttaqin, A. Z. 2014. Analisis Faktor-Faktor yang Mempengaruhi Sensitivitas Etika Auditor Pemerintah. Skripsi. Universitas Diponegoro. Semarang.

Nurfarida, L. 2011. Pengaruh Budaya Etis Organisasi dan Orientasi Etika terhadap Komitmen Organisasi dan Sensitivitas Etika Auditor (Studi pada Apartur Inspektorat Kabupaten Bogor). Skripsi. Universitas Islam Negeri Syarif Hidayatullah. Jakarta

Rest, J. R. 2000. A Neo-Kohlbergian Approach to Morality Research. Journal of Moral Education 29 (4).

Risa, N. 2011. Analisis Sensitivitas Etis Mahasiswa Universitas Islam 45 Bekasi. JRAK 1 (2): $1-15$.

Rotter, J. B. 1966. Generalized Expectancies for Internal Versus External Control of Reinforcement. Pscoholy Monokgrahs:General and Applied 80 (1).

Ryan, J. J. 2001. Moral Reasoning as a Determinant of Organizational Citizenship Behaviours: A Study in the Public Accounting Profession. Journal of Business Ethics. 33 (3): 233-244.

Salam, B. 2000. Etika Individual: Pola Dasar Filsafat Moral. Rineka Cipta. Jakarta.

Sari, T. Y. 2010. Hubungan Keharmonisan Keluarga dengan Penalaran Moral pada Remaja Delinkuen. Skripsi. Universitas Sumatera Utara. Medan.

Shaub, M. K. 1989. An Empirical Examination of the Determinants of Auditors' Ethical Sensitivity. PhD dissertation. Texas Tech University. Lubbock, TX.

Shaub, M. K. 1994. An Analysis of the Association of Traditional Demographic Variabels With The Moral Reasoning of Auditing Students and Auditors. Jounal of Accounting Aducation 2(1): 1-26.

Sinaga, M. S. 2015. Pengaruh Penalaran Etis, Orientasi Etis, Locus of Control, Gender dan Umur terhadap Sensitivitas Etis Mahasiswa Akuntansi. Skripsi. Universitas Diponegoro. Semarang.

Soehartono, I. 2004. Metode Penelitian Sosial: Suatu Teknik Penelitian Bidang Kesejahteraan Sosial dan Ilmu Sosial lainnya. PT Remaja Rosdakarya. Bandung 
Susanti, B. 2014. Pengaruh Locus of Control, Equity Sensitivity, Ethical Sensitivity dan Gender terhadap Perilaku Etis Akuntan (Studi Empiris Kantor Akuntan Publik Wilayah Padang dan Pekanbaru. Skripsi. Universitas Negeri Padang.

Sutiarsih, G. A., N. T. Herawati dan Ni K. Sinarwati. 2014. Pengaruh Budaya Etis Organisasi, Idealisme dan Relativisme terhadap Sensitivitas Etika Auditor (Studi Pada Aparatur Inspektorat Pemerintah Kabupaten Buleleng). Journal S1 Ak Universitas Pendidikan Ganesha 2 (1).

Tarigan, S. K. dan A. R. Siregar. 2013. Gambaran Penalaran Moral pada Remaja yang Tinggal di Daerah Konflik. Psikologia 8 (2): 79-88.

Uddin, N. and P. R. Gillet. 2002. The Effects of Moral Reasoning and Self-Monitoring on CFO Intentions to Report Fraudulently on Financial Statements. Journal of Business Ethics. Vol. 40 No.1, pp 15-32.

Widari, S. I. 2008 Pengaruh Religiusitas terhadap Penalaran Moral Remaja yang Beragama Islam Skirpsi. Universitas Sumatera Utara. Medan. 